УДК 378.1:811

\title{
ПЕДАГОГІЧНО-ПСИХОЛОГІЧНІ АСПЕКТИ КОМП'ЮТЕРНО- ОРІЄНТОВАНОГО ВИВЧЕННЯ ІНОЗЕМНИХ МОВ
}

\author{
В. П. Марценюк, Р. Б. Коцюба
}

ДВНЗ “Тернопільський держсавний медичний університет імені І. Я. Горбачевського МОЗ України”

\section{PEDAGOGICAL-PSYCHOLOGICAL ASPECTS OF COMPUTER- ASSISTED LEARNING OF FOREIGN LANGUAGES}

\author{
V. P. Martsenyuk, R. B. Kotsyuba \\ SHEI "Ternopil State Medical University by I. Ya. Horbachevsky of MPH of Ukraine"
}

\begin{abstract}
У статті розглянуто педагогічно-психологічні аспекти вивчення комп'ютерно-оріснтованого вивчення іноземних мов, звернено увагу на роль студентів і викладачів.
\end{abstract}

Pedagogical-psychological aspects of computer-assisted learning of foreign languages is dissolved in the article, role of students and teachers is taken into account.

Вступ. Використання мультимедійних комп'ютерно-орієнтованих середовищ відкриває нові можливості для розвитку мовних навичок. Використання електронних матеріалів на CD та DVD-дисках або Web-інтегрованих ресурсів робить заняття більш динамічними, концентрує увагу студентів, пропонує нові необтяжливі способи відпрацювання навичок прослуховування та мовлення. Збільшується мотивація студентів при виконанні завдань, які їм пропонуються, а отже, і якість засвоєння матеріалу.

Оскільки методика CALL (Computer-assisted language learning - прискорене вивчення мови за допомогою комп'ютера) є сучасною альтернативою до традиційних підходів, орієнтованих на викладача, то виникає багато запитань щодо іiі ефективності. Поперше, викладачі мови не сприймають ідею, що вони можуть бути усунені з процесу викладання іноземних мов. По-друге, нові віртуальні лінгафонні лабораторії вимагають від викладачів мови володіння технологіями та ресурсами. В таких умовах викладачі можуть зіткнутися з технічними проблемами та труднощами. Зважаючи на той факт, що багато викладачів мов не обізнані з комп'ютером так, як їх студенти, то, при запровадженні методики CALL, повинні бути докладені додаткові зусилля для узгодження компетентності викладачів 3 новим навчальним середовищем.

Основна частина. Існує ряд важливих переваг використання мультимедійних програм при викладанні іноземної мови.
Перш за все, потрібно взяти до уваги, що поєднання шляхів вивчення мови приводить до більшого успіху в освоєнні нової мови. Студенти вивчають достатньо багато часу мову за допомогою мультимедійних технологій і аудіювання в поєднанні з наочним матеріалом, які є досить важливими для сконцентрування уваги. Студент стає більш пильним до того, які зображення будуть показані на моніторі, і це пробуджує сенс передбачення, в якому студент більш активно залучається до вивчення змісту заняття. Таке середовище вивчення є більш подібним до такого в реальному світі, де аудіювання поєднане з візуальністю, яке спрямовує природний шлях студентського навчання, особливо тоді, коли вони ще діти. Зазвичай, комп'ютерне середовище, яке використовується на заняттях з іноземної мови, є більш принадним для сприйнятливих навиків, таких, як аудіювання і читання.

Комп'ютер не може оцінити безпосередньо експресивних навиків (говоріння і писання). Існуючі обмеження в комп'ютерних технологіях контролюють практику в говорінні і читанні. Досить успішним додатком у розпізнаванні автоматичного говоріння $\epsilon$ запропонована практика вимови, де комп'ютер дає зворотний зв'язок до точності артикуляції. До цього часу дана можливість є досить механічною і не заохочує розвиток можливостей в говорінні.

Прийнятними є чат і відеоконференція, які допомагають в говорінні і розмовних навиках. Все ще ці новинки, які надають практику в говорінні, допомага-

\footnotetext{
(ㄱ В. П. Марценюк, Р. Б. Коцюба
} 
ють студентам у розпізнаванні структур мови, зазвичай, використовуються поза межами класу, не включаючи контроль викладача $і$ його настанов. Існують деякі інші переваги, які мають психологічні виміри, які позитивно впливають на навчальний процес зі сторони студента.

Перш за все, комп'ютер зміщує центр уваги від викладача до студента. Оскільки присутність викладача є обмеженою, студент відчуває менший тиск при вивченні теми, на якій він постійно зосереджений. Пряма взаємодія студент-комп'ютер перерозподіляє увагу осіб, присутніх в класі, і це дає змогу студенту почуватися більш комфортно, забезпечуючи його самостійність. Результатом є краще виконання і знання.

У цьому випадку скромні чи менш здібні студенти почуваються більш вільними у відповідях на завдання. Вони мають більше досвіду і, більше того, більше вивчають. Необхідно згадати, що роль викладача не $є$ усуненою.

Звичайним явищем є те, що викладач вибирає i надає інформацію через комп'ютер. Він керує аудиторією, впроваджуючи особливі цілі, організовуючи підсумковий контроль, закріплюючи вивчений матеріал, спостерігаючи за розмовою в більшій обережності, порівнюючи із звичайним заняттям. Викладач має досить важливу суб'єктивну роль у вихвалянні і заохоченні до активної участі студентів, що є важливим у збереженні мотивації студентів.

Оскільки студенти мають більший контроль над процесом вивчення за допомогою комп'ютера, вони можуть вирішувати темп вивчення, який пропонує вирішення питань, які виникають між тими, які повільно чи швидко вивчають мову. Кожний студент може визначити свій особистий темп вивчення для отримання найкращих результатів. Вони не будуть почуватися розчарованими своїми оцінками і не буде нецікаво повторювати вивчені фрази.

Отже, використання комп'ютера для вивчення іноземної як другої мови має також психологічну користь, оскільки студенти почуваються більш впевненими, їх самоповага зростатиме і вони будуть задоволені свої успіхом. 3 боку користі, вони залучаються до творення процесу - вони вважають себе творцями їхнього навчального процесу. Таким чином вони стають більш відповідальними і більше усвідомлюють причетність до процесу вивчення.
Кажучи загалом, використання комп’ютерних технологій робить заняття більш цікавим. Викладач робить менше зусиль для привернення уваги студентів до важливості вивчення теми. Існують деякі проблеми, які прямо відносяться до обсягу вибраної теми для зосередження уваги і створення мотивації. Можна збільшити мотивацію в студентів, персоналізувавши дані про них. Наприклад, можна інтегрувати ім'я студентів чи створити деякий схожий контекст до їхніх особистих інтересів.

Зображення і предмети, які безпосередньо відносяться до життя студентів, можуть бути ефективними для зосередження уваги. Програми для студентів повинні використовувати зображення і розповіді, які надихають їх у формі світу фантастики: мультфільми, художні фільми й акторів. Також програма повинна запропонувати практичні навики, які об' єднують відхилення і зайнятість під час їх допитливості та інтересу для правильного виконання завдання.

Використання різноманітних мультимедійних компонентів запропоноване для того, щоб стимулювати зацікавленість студентів, підвищити їх мотивацію у проведенні більшого часу для виконання завдань 3 безпосередніми позитивними результатами для їх досягнення. Впроваджуючи принадні ситуації для використання мови, комп'ютер має дуже важливу роль у досягненні програми, яка навчає.

Найбільш важливим фактором в ефективності вивчення мови за допомогою комп'ютерних технологій $\epsilon$ здатність викладача контролювати баланс між студентом і комп'ютером. Існує ймовірність, що студент може бути настільки зацікавлений формою програми і рішенням завдань, через що не приділяє великої уваги вивченню мови.

Деякі студенти можуть зацікавитися зображеннями чи текстом і вони хочуть дізнатися більше, зайшовши далі, без серйозного виконання поставлених завдань. В результаті вони можуть автоматично виконати завдання без попереднього аудіювання за ілюстрованим словником чи не запам'ятають вимову або правила граматики.

Висновок. У статті розглянуто педагогічно-психологічні аспекти вивчення комп'ютерно-орієнтованого вивчення іноземних мов, зосереджено увагу на роль викладачів і студентів під час вивчення мови за допомогою методики CALL, виявлено позитивні і негативні сторони цієї методики. 


\section{Лiтература}

1. Bollin. G. G. The Realities of Middle School for Mexican Children / G. G. Bollin // The Clearing House. - 2003. - Vol 76 (4). - P. 198.

2. "Computer Assisted Language Learning : an Introduction". Warschauer Mark.

3. "CALL (computer assisted language learning) Guide to Good Practice 3". Davies Graham.

4. "Computer-assisted language learning: Increase of freedom of submission to machines?" (Domingo Noemi).

5. Ehsani Farzad. Speech technology in computer-aided language learning : Strengths and limitations of a new CALL paradigm // Farzad Ehsani, Eva Knodt // Language Learning and Technology .-1998. - Vol. 2 (1). - P. 45-60.

6. Mitchell R. Second Language Learning Theories //

R. Mitchell, F. Myles. - London : Arnold, 1998

7. Thelmadatter, Leigh (July/Sept 2007). "The Computers Are Coming ... Are Here!’. TESOL Greece Newsletter 95.

8. Traynor Patrick. Effects of computer-assisted instruction on different learners / Patrick Traynor // Journal of Instructional Psychology".-2003.

9. Ravichandran T. Computer-assisted language learning (CALL) in the perspective of the interactive approach : Advantages and apprehensions / T. Ravichandran. - 2000. 